Revista Brasileira de Farmacognosia Brazilian Journal of Pharmacognosy 21(4): 668-673, Jul./Aug. 2011

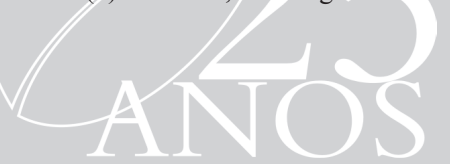

Article

Received 20 Aug 2010

Accepted 4 Nov 2010

Available online 20 May 2011

Keywords:

anticonvulsant

Citrus limon

essential oil

mice

ISSN 0102-695X

doi: $10.1590 / \mathrm{S} 0102-695 \mathrm{X} 2011005000086$

\section{Evaluation of central nervous system effects of Citrus limon essential oil in mice}

\author{
Lidianne Mayra Lopes Campêlo, ${ }^{1}$ Sidney Gonçalo de Lima, ${ }^{2}$ \\ Chistiane Mendes Feitosa, ${ }^{1,2}$ Rivelilson Mendes de Freitas ${ }^{*}, 1$
}

\author{
${ }^{1}$ Programa de Pós-graduação em Ciências Farmacêuticas, Núcleo de \\ Tecnologia Farmacêutica, Laboratório de Pesquisa em Neuroquímica \\ Experimental, Universidade Federal do Piaui, Brazil, \\ ${ }^{2}$ Departamento de Química, Universidade Federal do Piaui, Brazil.
}

\begin{abstract}
The central nervous system (CNS) depressant and anticonvulsant activities of Citrus limon (L.) Osbeck, Rutaceae, essential oil (EO) were investigated in animal models. The EO $(50,100$ and $150 \mathrm{mg} / \mathrm{kg})$ injected by oral route (p.o.) in mice caused a significant decrease in the motor activity of animals when compared with the control group, up to thirty days after the administration and the dose of $150 \mathrm{mg} / \mathrm{kg}$ significantly reduced the remaining time of the animals on the Rota-rod apparatus. Additionally, C. limon essential oil was also capable to promote an increase of latency for development of convulsions induced by pentylenetetrazole (PTZ). The administration of FLU $(10 \mathrm{mg} / \mathrm{kg}$, i.p.), GABA -benzodiazepine (GABA-BZD) receptor antagonist, antagonized the effect of $C$. limon essential oil at higher dose. This $C$. limon essential oil was also capable to promote an increase of latency for development of convulsions induced by picrotoxin (PIC) at higher dose. In the same way, the anticonvulsant effect of the EO was affected by pretreatment with flumazenil, a selective antagonist of benzodiazepine site of $\mathrm{GABA}_{\mathrm{A}}$ receptor. These results suggest a possible CNS depressant and anticonvulsant activities in mice that needs further investigation.
\end{abstract}

\section{Introduction}

The lemon [Citrus limon (L.) Osbeck, Rutaceae] exhibits many important natural chemical components, including citric acid, ascorbic acid, minerals and phenolic compounds, such flavonoids. Although their biological properties have always been associated with their content of vitamin $\mathrm{C}$, it has recently been shown that flavonoids and other nutrients and non-nutrients (vitamins, minerals, dietary fiber, essential oils and carotenoids). Play a role in this respect (Benavente-Garcia et al., 1997; Elangovan et al., 1944). Therefore, their health-promoting effects, such as obesity, diabetes, blood lipid lowering, cardiovascular diseases, brain disorders and certain types of cancer, have been associated with their contents, especially vitamin $\mathrm{C}$ and flavonoids, due to their natural antioxidant characteristics (Monforte et al., 1995; Miyake et al., 1997; Miyake et al., 1998; Rice-Evans et al., 1997; Tanaka et al., 1996).

Numerous herbal medicines are recognized as active in the central nervous system (CNS), and they have at least a hypothetical potential to affect chronic conditions such as anxiety, depression, headaches or epilepsy, that do not react well to conventional treatments (Carlini, 2003). Thus, C. limon essential oil may possess a modulatory role in the treatment of neurodegenerative diseases, since their phenolic compound can interrupts cellular oxidative processes in the central nervous system (CNS) (Rice-Evans et al., 1997). The effects of C. limon essential oil leaves in CNS have not yet been determined, therefore, it would be important to conduct these studies to clarify its brain action mechanism.

Preliminary behavioral screening performed with the lemon fruit demonstrates that it promotes sleep in dementia (Wolfe \& Herzberg, 1996), increasing motivational behaviour and improving disturbed behaviour (Brooker et al., 1997). Additionally, Nguyen \& Paton (2008) demonstrate an antinociceptive effect of lemon fruit on unspecific and specific tests. Since the role of C. limon on CNS property is little understood, we decided to assess the activities of Citrus limon essential oil (EO) in mice.

\section{Materials and methods}

Drugs 
The drugs used were: pentylenetetrazole (PTZ), picrotoxin (PIC), polyoxyethylene-sorbitan monolated (Tween 80) were purchased from Sigma (USA) and Diazepam (DZP) from Cristália (Brazil). Agents were orally (p.o.) or intraperitoneally (i.p.) administrated at a dose volume of $0.1 \mathrm{~mL} / 10 \mathrm{~g}$.

\section{Plant material and essential oil extraction}

The plant material was collected in February 2010, at the city of Picos, State of Piaui, Brazil, and their voucher was deposited at the Graziella Barroso Herbarium of the Federal University of Piaui under the voucher number 26.453. Samples of essential oils from the leaves of the Citrus limon (L.) Osbeck, Rutaceae, were prepared by Laboratory of Chemistry, UFPI (Matos et al., 1999).

The leaves of $C$. limon were dried in an oven with air renewal and circulation (model MA-037/18) at $40{ }^{\circ} \mathrm{C}$ until complete dehydration has been achieved. The essential oil was obtained by hydrodistillation in a Clevenger-type apparatus using 1,100 g of dried leaves. The oil obtained was dried over anhydrous sodium sulphate, producing yields of $0.32 \%(\mathrm{v} / \mathrm{w})$. GC-MS analysis was performed in a GC-17A/MS QP5050A GC/MS system (EI mode $70 \mathrm{eV}$, source temperature 270 ${ }^{\circ} \mathrm{C}$, scanned mass ranged 43-350 amu). The operating conditions were as follows: DB-5HT (J\&W Scientific, $30 \mathrm{~m} \times 0.25 \mathrm{~mm}$ i.d. $\times 0.10 \mathrm{~mm}$ film thickness); helium

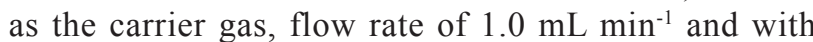
split ratio of $1: 30$; from $60{ }^{\circ} \mathrm{C}\left(2 \mathrm{~min}\right.$.) to $180{ }^{\circ} \mathrm{C}$ at $4{ }^{\circ} \mathrm{C} / \mathrm{min}$ and then from $180{ }^{\circ} \mathrm{C}\left(4 \mathrm{~min}\right.$.) to $260{ }^{\circ} \mathrm{C}$ at $10{ }^{\circ} \mathrm{C} / \mathrm{min}$, with a final hold of $10 \mathrm{~min}$ at $260^{\circ} \mathrm{C}$. The identity of each compound was determined by comparison of its retention index relative to $\mathrm{C}_{8}-\mathrm{C} 20$ $n$-alkanes (Fluka Analytical, $1.0 \mathrm{~mL}$ Alkane Standard Solution), as well as of its spectra with the Wiley 275. L data base (Alencar et al., 1984; 1990). The retention data (retention indices) were compared to those of the literature (Adams, 2007; Stenhagen et al., 1974).

\section{Animals}

Male Swiss mice (25-30 g), aging two months, were used. The animals were randomly housed in appropriate cages at $23 \pm 2{ }^{\circ} \mathrm{C}$ under $12 \mathrm{~h} \mathrm{light/dark}$ cycle (lights on 6:00-18:00 pm) with access to food $\left(\right.$ Purina $^{\circledR}$ ) and water ad libitum. All experiments were carried out between 8 am and $18 \mathrm{pm}$ in a quiet room. Experimental protocols and procedures were approved by the Ethics Committee on Animal Experiments at the Federal University of Piauí (CEEA/UFPI \# 44/09).

\section{Behavioral effects}

Behavioral screening of the mice $(n=7$ per group) was performed following parameters described by Almeida et al. (1999). The mice were observed during thirty days after oral treatment of $C$. limon essential oil $(50,100$ and $150 \mathrm{mg} / \mathrm{kg})$. It was observed the occurrence of the following general signs of toxicity: piloerection, prostration, writhing, increased evacuation, grooming, discrete groups, dyspnea, sedation, analgesia and palpebral ptosis.

\section{Locomotor activity}

Mice were divided into four groups of seven animals each and were treated orally with vehicle (saline/Tween 80 0.5\%; control group) or EO (50, 100 and $150 \mathrm{mg} / \mathrm{kg}$ ). The spontaneous locomotor activity of the animals was assessed in a cage activity $(50 \mathrm{~cm} \times 50$ $\mathrm{cm} \times 50 \mathrm{~cm}$ ) after thirty days of treatment (Asakura et al., 1993).

\section{Motor coordination test (rota-rod test)}

A Rota-rod tread mill device (AVS ${ }^{\circledR}$, Brazil) was used for the evaluation of motor coordination (Perez et al., 1998). Initially, the mice able to remain on the Rota-rod apparatus longer than $180 \mathrm{~s}$ (9 rpm) were selected $24 \mathrm{~h}$ before the test. Thirty minutes after thirty days of administration of either $C$. limon essential oil (50, 100 and $150 \mathrm{mg} / \mathrm{kg}$, p.o.), vehicle (saline/Tween $800.5 \%$; control group) or diazepam (DZP, $2.0 \mathrm{mg} / \mathrm{kg}$, i.p.), each animal was tested on the Rota-rod apparatus and the time (s) remained on the bar for up to $180 \mathrm{~s}$ was recorded after thirty days of treatment.

\section{Pentylenetetrazole (PTZ)-induced convulsions}

PTZ (60 mg/kg, i.p.) was used to induce clonic convulsions (Smith et al., 2007). Mice were divided into five groups ( $n=7$ per group), the first group served as control and received vehicle (saline/Tween 80 0.5\%) while the second group was treated with diazepam (DZP, $2.0 \mathrm{mg} / \mathrm{kg}$, i.p.). The remaining groups were treated during thirty days with $C$. limon essential oil $(50,100$ and $150 \mathrm{mg} / \mathrm{kg}$, p.o. $)$. After the treatment with $\mathrm{EO}$, the mice were treated with PTZ (i.p.) a single dose of $60 \mathrm{mg} / \mathrm{kg}$ (i.p.). The latency and percent of inhibition clonic convulsions were registered during 24 $\mathrm{h}$. The incidence of deaths was noted until $24 \mathrm{~h}$ after the injection of PTZ.

\section{Effects of flumazenil on PTZ-induced convulsion}

The effect of selective GABA -benzodiazepine $^{-}$ (GABA-BZD) receptor antagonist, flumazenil, on the anticonvulsant activity of EO was investigated. In the 
experimental groups, after thirty days of treatment with $\mathrm{EO}$, the mice were pre-treated with flumazenil (FLU) $(10 \mathrm{mg} / \mathrm{kg}$, i.p.) and thirty $\mathrm{min}$ before received $\mathrm{EO}$ $(150 \mathrm{mg} / \mathrm{kg}$, p.o.) or standard drug (DZP, $2.0 \mathrm{mg} / \mathrm{kg}$, i.p.). After thirty min of treatment with EO or DZP, the mice were treated with PTZ (i.p.) a single dose of 60 $\mathrm{mg} / \mathrm{kg}$ (i.p.) (File \& Pellow, 1986). The anticonvulsant activity of EO and DZP in mice pretreated with FLU was assessed.

\section{Picrotoxin (PIC)-induced convulsion}

Mice were divided into five groups ( $n=7$ per group), control group received vehicle (saline/Tween $800.5 \%$ ) and standard group was treated with diazepam (DZP, $2 \mathrm{mg} / \mathrm{kg}$, i.p.). The remaining groups were treated with 50,100 and $150 \mathrm{mg} / \mathrm{kg}$ of $\mathrm{EO}$ (p.o.). After thirty days of treatment with EO, the mice were treated with PIC at a dose of $8 \mathrm{mg} / \mathrm{kg}$ (i.p.). Immediately after the administration of the convulsant agent, mice were individually placed in plastic boxes and observed during $24 \mathrm{~h}$ for the time onset of clonic convulsion (latency), percent clonic convulsion and deaths. The incidence of deaths was noted until $24 \mathrm{~h}$ after the injection of PIC (Lehmann et al., 1988; Ngo Bum et al., 2001).

\section{Statistical analysis}

Data were evaluated by one-way analysis of variance (ANOVA) followed by Tukey's Multiple Comparison Test. The incidence (\%) of clonic or tonic-clonic convulsions as well as the mortality were evaluated by Fisher's Exact Test. Differences were considered to be statistically significant when $p<0.05$.

\section{Results}

Compounds of essential oil of $\mathrm{C}$. limon

GC-MS analysis showed a mixture of monoterpenes, being limonene $(52.77 \%)$, geranyl acetate $(9.92 \%)$ and trans-limonene-oxide $(7.13 \%)$ as the main compounds in $C$. limon essential oil (Table 1).

\section{Behavioral effects}

C. limon essential oil at doses of 50,100 and $150 \mathrm{mg} / \mathrm{kg}$, p.o. showed behavioral changes in animals thirty days after of treatment: decrease of spontaneous activity, palpebral ptosis, ataxia, analgesia, and sedation. Behavioral changes were more evident in the second day of treatments. These effects were apparently dose-dependent.
Table 1. Chemical composition and retention indices of the constituents of the Citrus limon (L.) Osbeck, Rutaceae, essential oil.

\begin{tabular}{clcc}
\hline $\mathrm{RT}_{(\mathrm{min})}{ }^{\mathrm{a}}$ & \multicolumn{1}{c}{ Compounds $^{\mathrm{b}}$} & $(\%)$ & $\mathrm{IK}^{\mathrm{c}}$ \\
\hline 4.785 & Limonene & 52.77 & 1025.5 \\
6.365 & Linalool & 1.73 & 1100 \\
7.137 & cis-Limonene-oxide & 2.68 & 1129.3 \\
7.253 & trans-limonene-oxide & 7.13 & 1133.7 \\
7.686 & Citronellal & 2.77 & 1150 \\
10.141 & Neral & 6.85 & 1238.5 \\
11.030 & Geranial & 5.49 & 1268.9 \\
13.062 & NI & 6.62 & 1337.8 \\
13.857 & Nerol & 4.04 & 1363.3 \\
14.441 & Geranyl acetate & 9.92 & 1384.2 \\
\hline & Total identified & 93.38 &
\end{tabular}

NI: Not identified; ${ }^{\mathrm{a} R e t e n t i o n ~ t i m e ; ~}{ }^{\circ} \mathrm{Compounds}$ listed in order of elution from an DB-5MS column; 'Kovats indices were calculated against $n$-alkanes $\left(\mathrm{C}_{9}-\mathrm{C}_{18}\right)$ on a DB-5MS column.

\section{Locomotor activity}

In doses of 50,100 or $150 \mathrm{mg} / \mathrm{kg}$ of $C$. limon essential oil caused significant decreases of 28, 29 and $79 \%$ of ambulation (number of crossings) at thirty days after administration, when compared to control group $(p<0.001)$, respectively (Figure 1). At dose of $150 \mathrm{mg} / \mathrm{kg}$ of $C$. limon essential oil caused significant decreases of 57 and $56 \%$ of ambulation at thirty days after administration, when compared to EO $50(p<0.001)$ and EO $100(p<0.001)$, respectively (Figure 1). Diazepam (2 mg/kg, i.p.) caused significant decrease of $81 \%$ of ambulation (number of crossings), when compared to control group $(p<0.001)$.

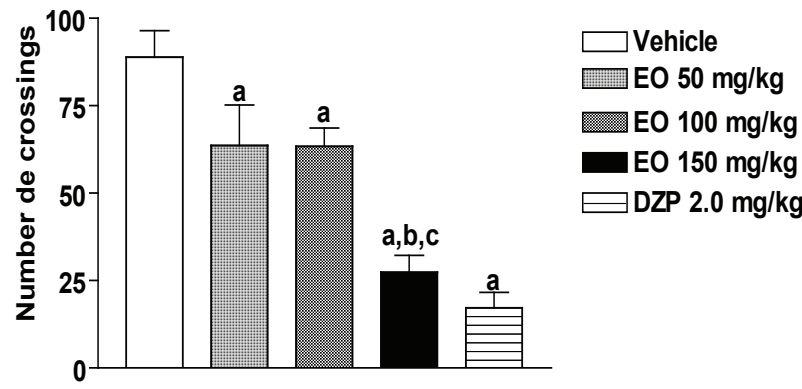

Figure 1. Effects of Citrus limon (L.) Osbeck, Rutaceae, essential oil (EO, 50, 100 and $150 \mathrm{mg} / \mathrm{kg}$, p.o.) or diazepam (DZP, $2.0 \mathrm{mg} / \mathrm{kg}$, i.p.) of mice locomotor activity. The parameters evaluated were the total number of pulses of crossings in activity cage. Values are the mean \pm S.E.M. $(n=7$ per group). ${ }^{\mathrm{a}} p<0.001$ (Fisher's test) compared to control; ${ }^{\mathrm{b}} p<0.001$ (Fisher`s test) compared to EO 50 group; ${ }^{c} p<0.001$ (Fisher`s test) compared to EO 100 group. 


\section{Motor coordination (Rota-rod test)}

In this test, thirty days after administration of $C$. limon essential oil only the dose of $150 \mathrm{mg} / \mathrm{kg}$ (p.o.) the remaining time of animals on the Rota-rod apparatus was significantly reduced in $30 \%$ (Figure 2 ). At dose of 150 $\mathrm{mg} / \mathrm{kg}$ of EO caused significant decreases of 28 and $27 \%$ of remaining time of animals on the Rota-rod apparatus at thirty days after administration, when compared to EO $50(p<0.001)$ and EO $100(p<0.001)$, respectively (Figure 2). Diazepam (2 mg/kg, i.p.) caused significant decrease of $56 \%$ of remaining time of animals on the Rota-rod apparatus, when compared to control group $(p<0.001)$.

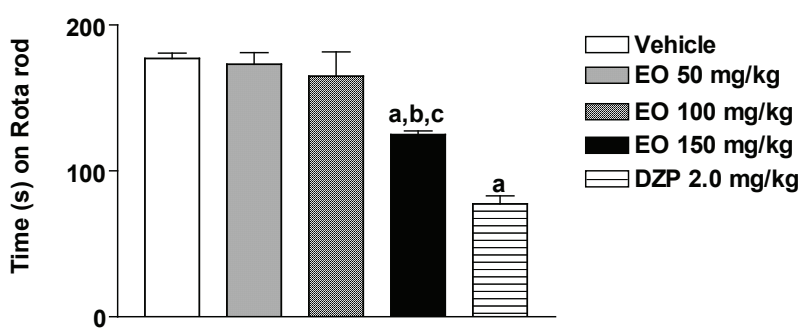

Figure 2. Time (s) on the Rota-rod observed in mice after oral route treatment with Vehicle (Control), Citrus limon (L.) Osbeck, Rutaceae, essential oil (EO, 50, 100 and $150 \mathrm{mg} /$ $\mathrm{kg}$, p.o.) or DZP $(2.0 \mathrm{mg} / \mathrm{kg}$, i.p. $)$. The motor response was recorded for the following $180 \mathrm{~s}$ after drug treatment. Values are the mean \pm S.E.M. ( $\mathrm{n}=7$ per group). ${ }^{\mathrm{a}} p<0.001$ (Fisher`s test) compared to control; ${ }^{\mathrm{b}} p<0.001$ (Fisher's test) compared to EO 50 group; ${ }^{c} p<0.001$ (Fisher`s test) compared to EO 100 group.

\section{Anticonvulsant activity}

Table 1 show that PTZ, in control group, clonic convulsions induced in $100 \%$ of mice. C. limon essential oil $(50,100$ and $150 \mathrm{mg} / \mathrm{kg}$, p.o.) delayed the onset of PTZ-induced tonic convulsion significantly. C. limon essential oil (150 mg/kg, p.o.) protected 85\% $(p<0.001)$ of mice against the convulsion and reduced in $60 \%$ the mortality rate induced by PTZ $(p<0.001)$. Diazepam $(2$ $\mathrm{mg} / \mathrm{kg}$, i.p.) completely protected the animals against the tonic convulsion elicited by PTZ.

As seen in Table 1, the administration of FLU (10 $\mathrm{mg} / \mathrm{kg}$, i.p.) antagonized the effect of $C$. limon essential oil $(150 \mathrm{mg} / \mathrm{kg}$, p.o.) and DZP $(2 \mathrm{mg} / \mathrm{kg}$, i.p. $)$ in the prolongation of convulsion latency.

When given p.o. only the highest dose of $C$. limon essential oil $(150 \mathrm{mg} / \mathrm{kg}$, p.o. $)$ increased the latency for convulsions and reduced mortality rate induced by PIC when compared to the negative control $(p<0.001)$ (Table 3).

\section{Discussion}

In Brazilian Northeast folk medicine, $C$. limon ("limoeiro") is used for treatment of dementia and oxidative damages. In the current study, the CNS depressant and anticonvulsant activities of $C$. limon leaf essential oil were investigated in different animal models. In pharmacological behavioral screening, the animals treated with EO showed decrease of response to the touch,

Table 2. Effects of Citrus limon (L.) Osbeck, Rutaceae, essential oil (EO) on PTZ-induced convulsion in mice.

\begin{tabular}{lcccc}
\hline \multicolumn{1}{c}{ Treatments } & Dose $(\mathrm{mg} / \mathrm{kg})$ & Latency $(\mathrm{s})$ & \% Inhibition of convulsion & \% Inhibition of death \\
\hline Vehicle & - & $126.3 \pm 11.9$ & 0 & 0 \\
EO 50 & 50 & $229.0 \pm 22.6^{\mathrm{a}}$ & 0 & 0 \\
EO 100 & 100 & $345.8 \pm 38.0^{\mathrm{b}}$ & 10 & $20^{\mathrm{e}}$ \\
EO 150 & 150 & $552.5 \pm 33.5^{\mathrm{c}}$ & $85^{\mathrm{d}}$ & $40^{\mathrm{d}}$ \\
EO+FLU & $150+10$ & $241.8+38.9$ & 0 & $15^{\mathrm{e}}$ \\
DZP & 2 & $852.9 \pm 10.0^{\mathrm{c}}$ & $100^{\mathrm{d}}$ & $100^{\mathrm{d}}$ \\
DZP+FLU & $2+10$ & $161.2+15.2$ & 0 & 15 \\
\hline
\end{tabular}

Values are the mean \pm S.E.M. mice ( $\mathrm{n}=7$ per group). ${ }^{\mathrm{a}} p<0.05$ (ANOVA followed by t-Student-Neuman-Keuls test) compared to control; ${ }^{\mathrm{b}} p<0.01$ (ANOVA followed by t-Student-Neuman-Keuls test) compared to control; ${ }^{c} p<0.001$ (ANOVA followed by t-Student-Neuman-Keuls test) compared to control; ${ }^{\mathrm{d}} p<0.001$ (Fisher`s test) compared to control; ${ }^{\mathrm{e}} p<0.05$ (Fisher`s test) compared to control.

Table 3. Effects of Citrus limon (L.) Osbeck, Rutaceae, essential oil (EO) on PIC-induced convulsion in mice

\begin{tabular}{lcccc}
\hline \multicolumn{1}{r}{ Treatments } & Dose $(\mathrm{mg} / \mathrm{kg})$ & Latency $(\mathrm{s})$ & \% Inhibition of convulsion & \% Inhibition of death \\
\hline Vehicle & - & $596.2 \pm 14.5$ & 0 & 0 \\
DZP & 2 & $1436.0 \pm 10.0^{\mathrm{a}}$ & $100^{\mathrm{a}}$ & $100^{\mathrm{a}}$ \\
EO 50 & 50 & $598.5 \pm 21.01$ & 0 & 0 \\
EO 100 & 100 & $597.5 \pm 45.9$ & 10 & 10 \\
EO 150 & 150 & $1205.9 \pm 29.3^{\mathrm{a}}$ & $60^{\mathrm{a}}$ & $60^{\mathrm{a}}$ \\
\hline
\end{tabular}

Values are the mean \pm S.E.M. ( $\mathrm{n}=7$ per group). ${ }^{\mathrm{a}} p<0.001$ (Fisher`s test) compared to control. 
palpebral ptosis, ataxia, analgesia, sedation and reduction of motor activity. These behavioral changes suggest a possible depressant effect on CNS and are similar to drugs that reduce the CNS activity (Morais et al., 2004; Netto et al., 2009; Almeida et al., 1999).

C. limon leaf essential oil at the highest dose (150 $\mathrm{mg} / \mathrm{kg}$ ) caused a significant reduction of ambulation of animals, corroborating with the hypothesis that $C$. limon essential oils reduce the CNS activity (Freire et al., 2006; Leite et al., 2008; Carlini, 2003; Quintans-Júnior et al., 2008).

The reduction of the locomotor activity might be due to either an inhibitory effect of the $C$. limon essential oil in CNS or by periphery muscular relaxant activity. So, this result indicates that EO could exhibit a sedative activity. Our GC-MS analysis revealed a mixture of monoterpenes (limonene, geranyl acetate and trans-limonene-oxide) as major compounds in EO and it can be able by inhibitory effects on CNS of mice observed during pharmacological behavioral screening after thirty days of treatment with EO (Passos et al., 2009).

In this context, to assess whether the $C$. limon essential oil produces loss of motor coordination of animals was performed to rota-rod apparatus. Once more, the results show that the highest dose produces loss of motor coordination in mice. Thus, the lack of motor coordination in the test of the Rota-rod is characteristic of a drug that reduces the CNS activity such as anxiolytics, sedatives and hypnotics (Almeida et al., 1999; Olayiwola et al., 2007; Dallmeier \& Carlini, 1981).

The beginning of tonic-clonic convulsion produced by PTZ was significantly delayed by $C$. limon essential oil and the incidence of mortality was reduced. According to De Sarro et al. (1999), PTZ may be exerting its convulsant effect by inhibiting the activity of gamma aminobutyric acid (GABA) at $\mathrm{GABA}_{\mathrm{A}}$ receptors. GABA is the the epilepsy key inhibitory neurotransmitter. The enhancement and inhibition of the neurotransmission of GABA frequently attenuate and enhance convulsion, respectively (Westmoreland et al., 1994). Since the C. limon essential oil postponed the occurrence of convulsions, it is probable that it had been caused by the neurotransmission GABAergic activation (Nicoll, 2001; Rang et al., 2003).

In order to determine the role of GABA-BZD receptors participation in the $C$. limon essential oil-induced anticonvulsant effects, flumazenil (FLU), a specific antagonist of the benzodiazepine site in the GABA-BZD receptor complex, was used (File \& Pellow, 1986). Mice pretreated with FLU in the PTZ-induced convulsion model suggest that the EO may facilitate the inhibitory activity of the GABAergic system probably through a competitive agonist action in the BZD site of the GABA receptors. The significantly effect on the motor coordination, in higher doses, can support this theory, since GABAergic drugs usually are sedative (Pedersen et al., 2009).
According to Nicoll (2001), picrotoxin, a $\mathrm{GABA}_{\mathrm{A}}$-receptor antagonist, produces seizures by blocking the chloride-ion channels linked to $\mathrm{GABA}_{\mathrm{A}}-$ receptors, thus preventing the entry of chloride ions into the brain inhibiting, consequently, the brain transmission (Löscher \& Schmidt, 2006). Therefore, the findings of the present study suggest that C. limon essential oil $(150 \mathrm{mg} /$ $\mathrm{kg}$, p.o.) has inhibited and/or attenuated the PIC-induced convulsions of mice by interfering with GABAergic neurotransmission (Oliveira et al., 2001).

Summarizing our data, the results propose a possible depressant CNS and anticonvulsant effects of $C$. limon essential oil. The precise mechanisms of possible behavioral effects of $C$. limon essential oil are not clear, however, GABAergic neurotransmitter system might be involved. Thus, further investigations are in progress for elucidation of this effect in CNS.

\section{Acknowledgment}

We would like to thank the National Council of Technological and Scientific Development (CNPq/ Brazil) [grant number 503354/2009-0] and the Research Supporting Foundation of State of Piaui (FAPEPI/Brazil) for the financial support and Dr. Paulo Michel Pinheiro Ferreira (UFPI, Picos) for his help with English editing of the manuscript.

\section{References}

Adams RP 2007. Identification of essencial oil components by gas chromatography/massa spectroscopy. Allured: Baylor University.

Alencar JW, Craveiro AA, Matos FJA 1984. Kovats' indices as a preselection routine in mass spectra library search of volatiles. J Nat Prod 47: 890-892.

Alencar JW, Craveiro AA, Matos FJA, Machado MIL 1990. Kovats indices simulation in essential oils analysis. Quim. Nova 13: 282-284.

Almeida RN, Falcão ACGM, Diniz RST, Quintans-Júnior LJ, Polari RM, Barbosa-Filho JM, Agra MF, Duarte JC, Ferreira CD, Antoniolli AR, Araújo CC 1999. Metodologia para avaliação de plantas com atividade no sistema nervoso central e alguns dados experimentais. Rev Bras Farm 80: 72-76.

Asakura W, Matsumoto K, Ohta H, Watanbe H 1993. Effects of alpha 2-adrenergic drugs on REM sleep deprivationinduced increase in swimming activity. Pharmacol Biochem Behav 46: 111-115.

Benavente-Garcia O, Castillo J, Marın JR, Ortuno A, Del Rio JA 1997. Uses and properties of Citrus flavonoids. J Agricul Food Chem 45: 4505-4515.

Brooker DJR, Snape M, Johnson E, Ward D, Payne M 1997. Single case evaluation of the effects of aromatherapy and massage on disturbed behaviour in severe dementia Brit J Clin Psychol 36: 287-296.

Carlini EA 2003. Plants and the central nervous system. Pharmacol Biochem Behav 75: 501-512. 
Dallmeier K, Carlini EA 1981. Anesthetic, hypotermic, myorelaxant and anticonvulsant effects of synthetic eugenol derivatives and natural analogues. Pharmacology 22: 113-127.

De Sarro A, Cecchetti V, Fravolini V, Naccari F, Tabarrini O, De Sarro G 1999. Effects of novel 6-desfluoroquinolones and classic quinolones on pentylenetetrazole-induced seizures in mice. Antimicrob Agents Chemother 43: 1729-1736.

Elangovan V, Sekar N, Govindasamy S 1994. Chemoprotective potential of dietary bioflavonoids aginst 20-methylchloranthrene-induced tumorogenesis. Cancer Lett 87: 107-113.

File SE, Pellow S 1986. Intrinsic actions of the benzodiazepine receptor antagonist Ro 15-1788. Psychopharmacology 88: 1-11.

Freire CMM, Marques MOM, Costa, M 2006. Effects of seasonal variation on the central nervous system activity of Ocimum gratissimum L. essential oil. J Ethnopharmacol 105: 161-166.

Leite MP, Fassin Jr J, Baziloni EMF, Almeida RN, Mattei R, Leite JR 2008. Behavioral effects of essential oil of Citrus aurantium L. inhalation in rats. Rev Bras Farmacogn 18: 661-666.

Lehmann J, Hutchison A, McPherson SE, Mondadori C, Schmutz M, Sinton CM, Tsai C, Murphy DE, Steel DJ, Williams M, Cheney DL, Wood PL 1988. CGS 19755 a selective and competitive $\mathrm{N}$-metil-D-aspartate-type excitatory amino acid receptor antagonist. J Pharmacol Exp Ther 246: 65-75.

Löscher W, Schmidt D 2006. New horizons in the development of antiepileptic drugs: Innovative strategies. Epilepsy Res 69:183-272.

Matos FJA, Machado MIL, Craveiro AA, Barbosa-Filho JM 1999. Essential oil of Mentha x villosa Huds. $J$ Essent Oil Res 11: 41-44.

Miyake Y, Yamamoto K, Morimitsu Y, Osawa T 1997. Isolation of C-glucosylflavone from lemon peel and antioxidative activity of flavonoid compounds in lemon fruit. J Agricul Food Chem 45: 4619-4623.

Miyake Y, Yamamoto K, Morimitsu Y, Osawa T 1998. Characterization of antioxidative flavonoids glycosides in lemon fruit. F Sci Tech Int Tokyo 4: 48-53.

Monforte MT, Trovato A, Kirjarainen S, Forestieri AM, Galati EM, Lo Curto RB 1995. Biological effects of hesperidin a Citrus flavonoid. (Note II): Hypolipidemic activity on experimental hypercholesterolemia in rat. Farmaco 9: 595-599.

Morais LCSL, Quintans-Júnior LJ, Franco CIF, Almeida JRGS, Almeida RN 2004. Antiparkinsonian-like effects of Plumbago scandens on tremorine-induced tremors methodology. Pharmacol Biochem Behav 79: 745-749.

Netto SM, Warela RWB, Fechine MF, Queiroga MN, QuintansJúnior LJ 2009. Anxiolytic-like effect of Rauvolfia ligustrina Willd. Ex Roem. \& Schult. Apocynaceae, in the elevated plus-maze and hole-board tests. Rev Bras Farmacogn 19: 888-892.

Nicoll RA 2001. Introduction to the pharmacology of the central nervous system (CNS). In: Katzung BG (ed.) Basic and Clinical Pharmacology. 8. ed. New York: McGraw-Hill, p. 351-363.
Ngo Bum E, Schmutz M, Meyer C, Rakotonirina A, Bopelet M, Portet C, Jeker A, Rakotonirina SV, Olpe HR, Herrling P 2001. Anticonvulsant properties of the methanolic extract of Cyperus articulatus (Cyperaceae). J Ethnopharmacol 76: $145-150$

Nguyen QA, Paton C 2008. The use of aromatherapy to treat behavioral problems in dementia. Int J Geriatr Psychiatry 23: 337-346.

Olayiwola G, Obafemi CA, Taiwo FO 2007. Synthesis and neuropharmacological activity of some quinoxalinone derivatides. Afr J Biotechnol 6: 777-786.

Oliveira FA, Almeida RN, Sousa MFV, Barbosa-Filho JM, Diniz SA, Medeiros IA 2001. Anticonvulsant properties of N-salicyloyltryptamine in mice. Pharmacol Biochem Behav 68: 199-202.

Passos CS, Arbo MD, Rates SMK, Von Poser GL 2009. Terpenóides com atividade sobre o Sistema Nervoso Central (SNC). Rev Bras Farmacogn 19: 140-149.

Perez GRM, Perez LJA, Garcia DLM, Sossa MH 1998. Neuropharmacological activity of Solanum nigrum fruit. J Ethnopharmacol. 62: 43-48.

Pedersen ME, Vestergaard HT, Hansen SL, Bah S, Diallo D, Jäger AK 2009. Pharmacological screening of Malian medicinal plants used against epilepsy and convulsions. J Ethnopharmacol 121: 472-475.

Quintans-Júnior LJ, Souza TT, Leite BS, Lessa NMN, Bonjardim LR, Santos MRV, Alves PB, Blank AF, Antoniolli AR 2008. Phythochemical screening and anticonvulsant activity of Cymbopogon winterianus Jowitt (Poaceae) leaf essential oil in rodents. Phytomedicine 15: 619-624.

Rang HP, Dale MM, Ritter JM, Moore PK 2003. Pharmacology, 5 ed. Edinburgh: Churchill Livingstone, p 585-587.

Rice-Evans CA, Miller NJ, Paganda G 1997. Antioxidant properties of phenolic compounds. Trends Plant. Sci. 2: 152-159.

Smith M, Wilcox KS, White HS 2007. Discovery of antiepileptic drugs. Neurotherapeutics 4: 12-17.

Stenhagen E, Abrahamson S, McLafferty FW 1974. Registry of mass spectra data base. Washington DC: Government Printing Office.

Tanaka T, Makita H, Mori H 1996. Chemoprotection of 4-NOOinduced oral carcinogenesis by dietary flavonoids diosmin and hesperidin. Rect Adv Gastroenter Carcinog 1: $1167-1170$.

Westmoreland BF, Benarroch EE, Dube JR, Regan TJ, Sandok BA 1994. Medical Neurosciences. Rochester: Mayo Foundation, p 307-312.

Wolfe N, Herzberg J 1996. The study protocol of a blinded randomized-controlled cross-over trial of lavender oil as a treatment of behavioural symptoms in dementia. Int $J$ Geriatr Psychiatry 11: 926-927.

\section{*Correspondence}

Rivelilson Mendes de Freitas

Laboratório de Pesquisa em Neuroquímica Experimental, Universidade Federal do Piauí

Campus Universitário Ministro Petrônio Portella, Curso de Farmácia, Bairro Ininga, 64.049-550 Teresina-PI, Brazil

rivelilson@pq.cnpq.br

Tel. +55863215 5870 